\title{
Monocolonization with Bacteroides ovatus Protects Immunodeficient SCID Mice from Mortality in Chronic Intestinal Inflammation Caused by Long-Lasting Dextran Sodium Sulfate Treatment
}

\author{
T. HUDCOVIC, H. KOZÁKOVÁ, J. KOLÍNSKÁ ${ }^{1}$, R. ŠTĚPÁNKOVÁ, T. HRNČÍŘ, \\ H. TLASKALOVÁ-HOGENOVÁ
}

Institute of Microbiology, Department of Immunology and Gnotobiology, Academy of Sciences of the Czech Republic, Nový Hrádek and ${ }^{1}$ Institute of Physiology, Academy of Sciences of the Czech Republic, Prague, Czech Republic

Received July 3, 2007

Accepted November 30, 2007

On-line January 17, 2008

\section{Summary}

This study was aimed to evaluate the role of commensal Gramnegative bacterium Bacteroides ovatus in murine model of chronic intestinal inflammation. The attempt to induce chronic colitis was done in Bacteroides ovatus-monoassociated, germfree and conventional mice either in immunocompetent (BALB/C) mice or in mice with severe combined immunodeficiency (SCID), using $2.5 \%$ dextran-sodium sulfate (DSS) in drinking water (7 days DSS, 7 days water, 7 days DSS). Conventional mice developed chronic colitis. Some of germ-free BALB/C and the majority of germ-free SCID mice did not survive the long-term treatment with DSS due to massive bleeding into the intestinal lumen. However, monocolonization of germ-free mice of both strains with Bacteroides ovatus prior to long-term treatment with DSS protected mice from bleeding, development of intestinal inflammation and precocious death. We observed that though DSS-treated Bacteroides ovatus-colonized SCID mice showed minor morphological changes in colon tissue, jejunal brushborder enzyme activities such as $\mathrm{y}$-glutamyltranspeptidase, lactase and alkaline phosphatase were significantly reduced in comparison with DSS-untreated Bacteroides ovatus-colonized mice. This modulation of the enterocyte $\mathrm{y}$-glutamyltranspeptidase localized to the brush border membrane has been described for the first time. This enzyme is known to reflect an imbalance between pro-oxidant and anti-oxidant mechanisms, which could be involved in protective effects of colonization of germ-free mice with Bacteroides ovatus against DSS injury.

\section{Key words}

Bacteroides ovatus • Ulcerative colitis • Dextran sulfate sodium colitis • Gnotobiotic mice

\section{Corresponding author}

H. Kozáková, Department of Immunology and Gnotobiology, Academy of Sciences of the Czech Republic. CZ-549 22 Nový Hrádek, Czech Republic. Fax +420491478264. E-mail: kozakova@biomed.cas.cz

\section{Introduction}

Ulcerative colitis and Crohn's disease are relapsing inflammatory disorders of the colon of unknown origin in which genetic, immunological and environmental factors may be involved. Critical role in the etiology of these inflammatory bowel diseases (IBD) is played by intestinal microflora (Tlaskalová-Hogenová et al. 2005). Abnormalities have been described in the fecal microbiota of patients with IBD. Genus Bacteroides - B. vulgatus, B. fragilis, B. merdae distasonis, B. ovatus, $B$. thetaiotaomicron and $B$. uniformis - was found to be increased in colon of patients with ulcerative colitis (Poxton et al. 1997, Sokol et al. 2006). The higher incidence of population of members of the Bacteroides in ulcerative colitis patients suggests that these may have an influence on the pathogenesis of the disease (Lucke et al. 2006). Saitoh et al. (2002) described that B. ovatus is the predominant commensal intestinal microbe causing a systemic antibody response in inflammatory bowel diseases. In experimental animals such as mice the development of the inflammation is influenced by mouse strains used for the experiments, induction agents 
and length of treatment responsible for induction of inflammation. Interestingly, after the induction of experimental colitis when BALB/c mice are kept in sterile environments they develop markedly weaker colonic inflammation than their conventional (CV) counterparts (Hudcovic et al. 2001). In recent years, monocolonization of germ-free (GF) animals with single bacterial strain enables to demonstrate the influence on immunological and physiological characteristics of gastrointestinal tract. Thus, $B$. thetaiotaomicron as a main representative of mouse colon was used for monocolonization of GF mice and was demonstrated to affect several gene expressions (Hooper et al. 2001, Hooper 2004). A widely used experimental model of colitis involving oral consumption of dextran sulfate sodium (DSS) dissolved in drinking water results in an acute distal colitis in rodents, which resembles human ulcerative colitis in both clinical and histopathological findings (Okayasu et al. 1990). Histologically the acute phase was characterized by destruction of the colonic epithelial layer and mucosal infiltration of neutrophils, macrophages and lymphocytes (Okayasu et al. 1990, Cooper et al. 1993); the chronic phase was characterized mainly by mononuclear cell infiltration and significant increases in leukocyte-endothelium interactions and leukocyte extravasations (Farkas et al. 2001). Axelsson et al. (1996) studied in detail the involvement of immunological mechanisms in DSSinduced colonic inflammation. The authors tested $\mathrm{BALB} / \mathrm{c}$ mice depleted of $\mathrm{CD} 4^{+} \mathrm{T}$ cells, athymic mice, $\mathrm{T}$ and $\mathrm{B}$ cells deficient SCID mice and SCID mice depleted of NK cells. They concluded that the presence of functional T, B and NK cells is not crucial for the induction of DSS colitis in mice and thus confirmed the results of Dieleman et al. (1994). Previously we demonstrated that SCID mice are sensitive to DSS treatment depending on microbial colonization (Hudcovic et al. 2001). B. ovatus known to cause systemic antibody response in patients with IBD (Saitoh et al. 2002), has not been tested on development of experimental colitis induced by DSS.

Here we studied whether $B$. ovatus monocolonization of GF mice of two strains - SCID and BALB/c mice - affected the severity of colonic inflammation after long-term DSS treatment. Study was completed by determination of the expression of brushborder enzymes of the small intestinal mucosa where no direct inflammation has been noticed.

\section{Methods}

\section{Animals}

Two-month-old BALB/c and SCID mice (mice with severe combined immunodeficiency, background BALB/cJHanHsd-SCID) were used for our experiments. Germ-free and B. ovatus-associated mice were kept in sterile conditions in separate plastic transparent cages in isolators and fed ad libitum sterile (59 kGy irradiated) standard pellet diet (ST1, Inst. Physiol., Acad. Sci. Czech Republic) and sterile water. Conventional mice kept in the $\mathrm{CV}$ animal facility were fed the same but not sterile food. The animals were kept in a room with a $12 \mathrm{~h} \mathrm{light-}$ dark cycle at $22{ }^{\circ} \mathrm{C}$ (Štěpánková 1997). There were 7 to 18 mice in each experimental group.

\section{Experimental design and induction of colitis}

Outline of experimental groups is described in

Table 1. The group of GF mice was monocolonized with B. ovatus, a species of Gram-negative obligate anaerobes found in the human colon (kind gift of Dr. Elena Verdu, University of Lausanne, Switzerland) in concentration $10^{7} \mathrm{CFU}$ in $0.2 \mathrm{ml}$ of phosphate buffer solution (PBS) by intragastrical tubing at weaning (21-day-old) and the second generation of mice was used in our experiment. Other groups of mice that remained GF as well as and CV mice served as controls. At the age of two months, the chronic colitis was induced in mice by replacing drinking water with water containing $2.5 \%$ DSS (wt/vol; m.w. $40 \mathrm{kD}$; ICN Biomedicals, USA) according to the following schedule: 7 days $2.5 \%$ DSS -7 days water 7 days $2.5 \%$ DSS, allowing the mice to drink freely. Clinical symptoms such as diarrhea, bleeding and enteric rectal prolapse and changes in body weight were tested. The animals were sacrificed in ether anesthesia by exsanguination. The whole intestine was removed. Jejunum was washed with cold saline and jejunal scrapings were used for brush border membrane isolation. Colon descendens was evaluated histologically. All experiments were approved by the Ethical Committee of the Institute according to the Animal Protection Act.

\section{Histology}

The colon tissue was fixed in Carnoy's fluid for 30 min and transferred into $96 \%$ ethanol overnight, then via $100 \%$ ethanol $(3 \times 1 \mathrm{~h})$ into methylsalicylate $(4 \mathrm{~h} /$ overnight $/ 4 \mathrm{~h})$, benzene $(3 \times 10 \mathrm{~min})$ and benzene paraffin $(30 \mathrm{~min})$ to paraffin $(2 \mathrm{x}$ overnight). The tissue specimens were sliced into sections $5 \mu \mathrm{m}$ thick. All 
Table 1. Outline of experimental groups involved in the study

\section{Experimental group}

Germ-free mice (BALB/c)

Germ-free mice (SCID)

B. ovatus-monocolonized (BALB/c)

B. ovatus-monocolonized (SCID)

B. ovatus-monocolonized (SCID)

Conventional mice (BALB/c)

Conventional mice (SCID)

\section{Treatment with DSS}

7-day-DSS, 7-day-water, 7-day-DSS

7-day-DSS, 7-day-water, 7-day-DSS

7-day-DSS, 7-day-water, 7-day-DSS

7-day-DSS, 7-day-water, 7-day-DSS

untreated

7-day-DSS, 7-day-water, 7-day-DSS

7-day-DSS, 7-day-water, 7-day-DSS

Table 2. Effect of chronic ulcerative colitis on mortality, histopathological score in colon descendens and mucin production in $B$. ovatusmonocolonized, GF and CV BALB/C and SCID mice

\begin{tabular}{llll} 
Experimental groups & Mortality/number & Damage score & Mucin secretion \\
\hline B. ovatus-monocolonized (BALB/c) & $0 / 7$ & $0-1$ & $3-4$ \\
Germ-free mice (BALB/c) & $3 / 8$ & $1-2$ & $2-3$ \\
Conventional mice (BALB/c) & $2 / 10$ & 4 & 0 \\
B. ovatus-monocolonized (SCID) & $0 / 18$ & $1-2$ & $2-3$ \\
Germ-free mice (SCID) & $7 / 8$ & n.d.* & n.d.* \\
Conventional (SCID) & $6 / 12$ & 4 & 0 \\
\hline
\end{tabular}

*not done, impossible to evaluate because of high mortality rate

specimens were stained with hematoxylin-eosin, Cresyl Fast Violet (both Vector, USA). The specimens were viewed under Olympus BX 40 microscope equipped with a digital camera Olympus Camedia C-2000. Photographs were taken on proposal of Camedia Master 2.5 and Olympus DP-Soft. The four degrees of damage to the surface epithelium and crypt distortion in individual colon segments were evaluated according to Cooper et al. (1993). The secretion of mucin was assessed in four categories in cross sections: 1 - secretion of mucin on $25 \%$ of the colon surface, 2 - secretion of mucin on $50 \%$ of the colon surface, 3 - secretion of mucin on $75 \%$ of the colon surface, and $4-$ secretion of mucin on $100 \%$ of the colon surface.

\section{Immunohistochemistry}

Colon descendens segments were frozen in liquid nitrogen. Acetone-fixed sections $5 \mu \mathrm{m}$ thick were used for immunohistochemistry. The membrane marker CD11b was detected directly by fluorescein-labeled monoclonal antibody to CD11b/FITC (MCA $74 \mathrm{~F}$, Serotec, Oxford, UK). The surface antigen CD11b is known to be expressed on the surface of polymorphonuclear leukocytes, monocytes and NK cells.

Preparation of enterocyte brush-border membrane vesicles

Brush border membranes were prepared from jejunal scrapings essentially according to the method of Kessler et al. (1978).

\section{Determination of enzyme activities}

Lactase of the lactase-phlorizin hydrolase complex (EC 3.2.1.23/62/108), sucrase of the sucraseisomaltase complex (EC 3.2.1.48/10) and glucoamylase of the maltase-glucoamylase complex (EC 3.2.1.20/3) activities were determined with $50 \mathrm{mM}$ lactose (Kraml et al. 1972), $50 \mathrm{mM}$ sucrose and $12 \mathrm{~g} / 1$ of starch as substrates, respectively (Kolínská and Kraml 1972). The liberated glucose was measured with the Tris-glucose oxidaseperoxidase reagent (Dahlqvist 1964). Alkaline phosphatase (EC 3.1.3.1) activity was determined in BBMV with 0.1 $\mathrm{mM}$ p-nitrophenylphosphate (Fluka, Buchs, Switzerland) as substrate in Tris- $\mathrm{HCl}$ buffer $(\mathrm{pH} \mathrm{8.5)}$. The liberated $\mathrm{p}$ nitrophenol was measured at $\mathrm{A}_{405}$ using the Test Kit (Lachema, Brno, Czech Republic). The activity of $\gamma$ - 

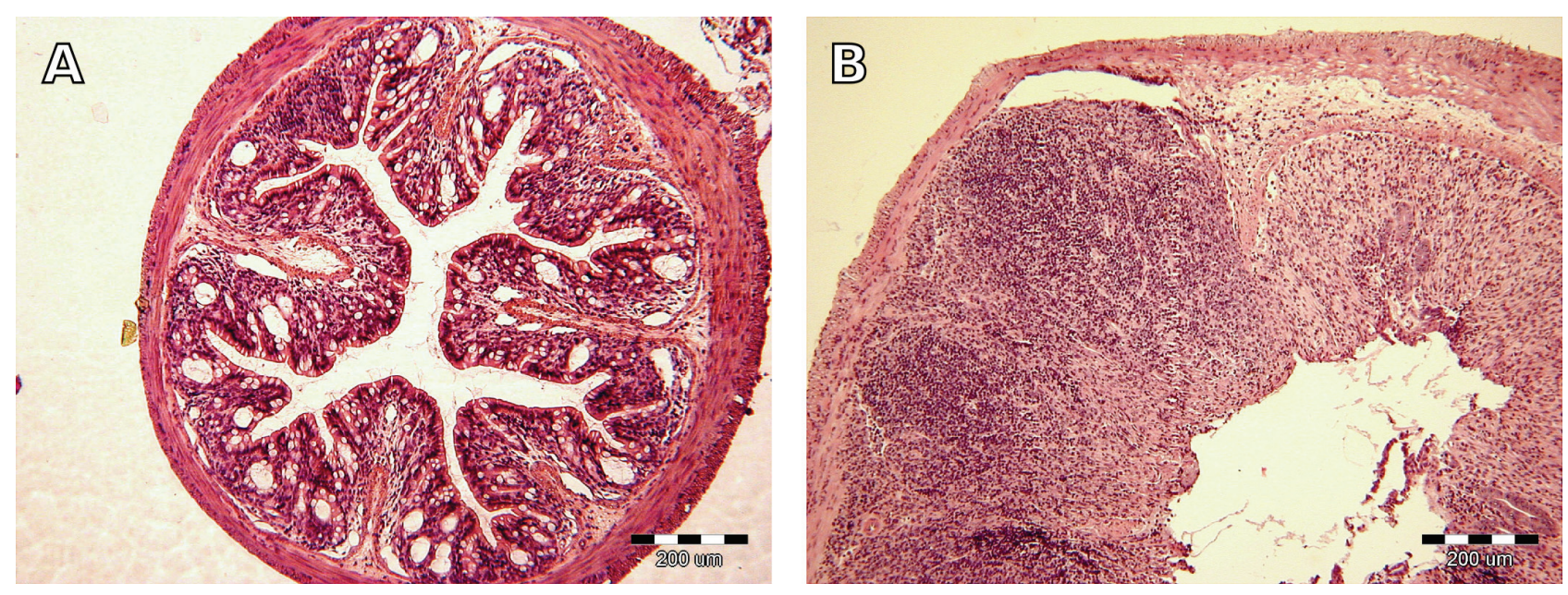

Fig. 1. Representative cross-sectional views of hematoxylin and eosin stained colon descendens of (A) GF BALB/C mice (damage grade $1-2$, mucin secretion 2 - 3) compared with damaged colon descendens of (B) CV BALB/C mice (damage grade 4 , mucin secretion 0 ) in a chronic model of ulcerative colitis.
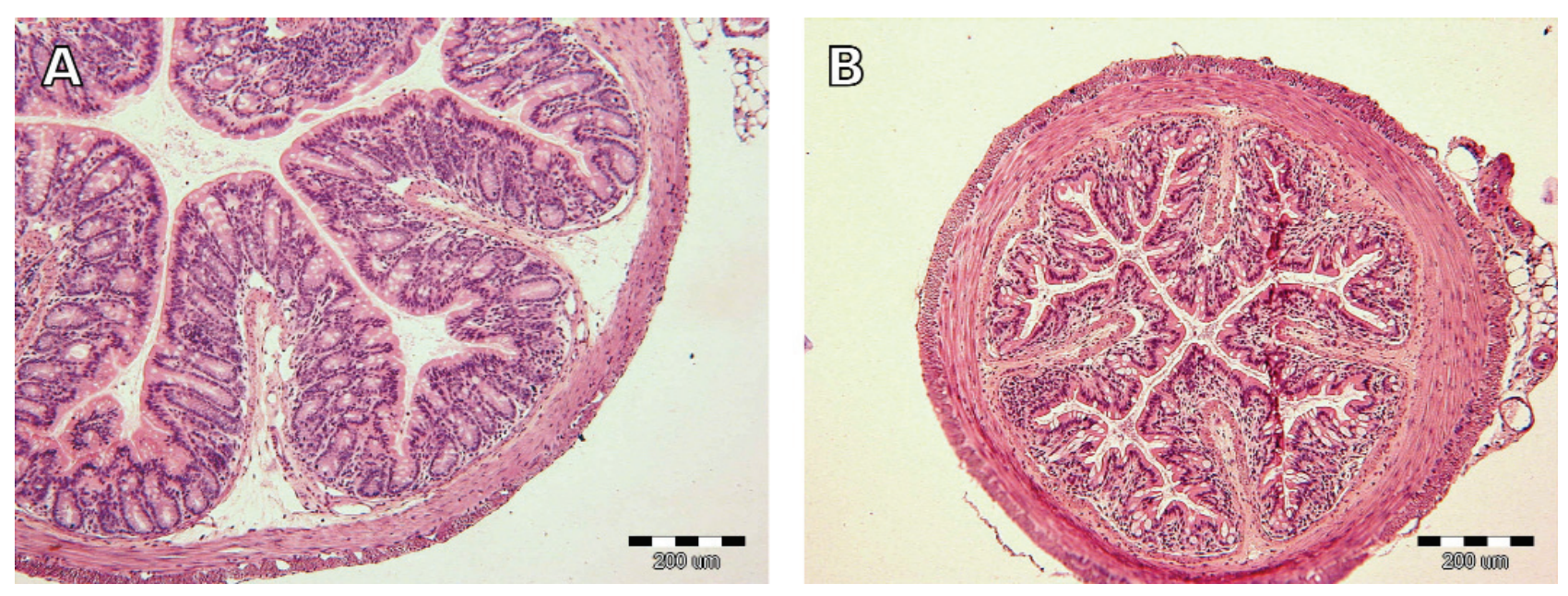

Fig. 2. Representative cross-sectional views of hematoxylin and eosin stained colon descendens in a chronic model of ulcerative colitis of (A) B. ovatus-monoassociated BALB/c mice (damage grade $0-1$, mucin secretion $3-4$ ) and mild changes in colonic submucosa in (B) B. ovatus-monoassociated SCID mice (damage grade $1-2$, mucin secretion 2 - 3).

glutamyltranspeptidase (GGT; EC 2.3.2.2) was determined with $7 \mathrm{mM}$ 5-L-glutamic acid-4-nitroanilide (Fluka, Buchs, Switzerland) as donor substrate, $0.1 \mathrm{mM}$ glycylglycine ( $\mathrm{pH}$ 8.2; Fluka, Buchs, Switzerland) as acceptor substrate and $0.1 \mathrm{mM} \mathrm{NaCl}$ as activator. Released 4-nitroaniline was measured at $\mathrm{A}_{405}$ (Thompson et al. 1976). The activity of dipeptidyl peptidase IV (DPP IV; EC 3.4.14.5) was determined with $1.4 \mathrm{mM}$ glycyl-L-proline-4-nitroanilide (Sigma-Aldrich, Diesenhofen, Germany) in $66 \mathrm{mM}$ Tris$\mathrm{HCl}$ buffer, $\mathrm{pH}$ 8.0. The reaction was stopped with $1 \mathrm{mM}$ Na-acetate buffer ( $\mathrm{pH} 4.2)$ and the released 4-nitroaniline was measured at $\mathrm{A}_{405}$ (Nagatsu et al. 1976). Enzyme activities were expressed as nkat/mg protein, one nanokatal being the amount of the enzyme that converts 1 nanomole of substrate per second under the given conditions. Protein in BBMV was determined by the method of Lowry et al. (1951) using bovine serum albumin, fraction V (Serva, Heidelberg, Germany) as standard.

\section{Statistical analysis}

The results were expressed as means \pm S.D. Statistical analyses were performed using SigmaStat (Jandel Corporation). Multiple comparison procedures were made by one way analysis of variance (ANOVA), Student-Newman-Keuls method. Values of $\mathrm{p}<0.05$ were considered significant.

\section{Results}

The majority of GF SCID mice did not survive 

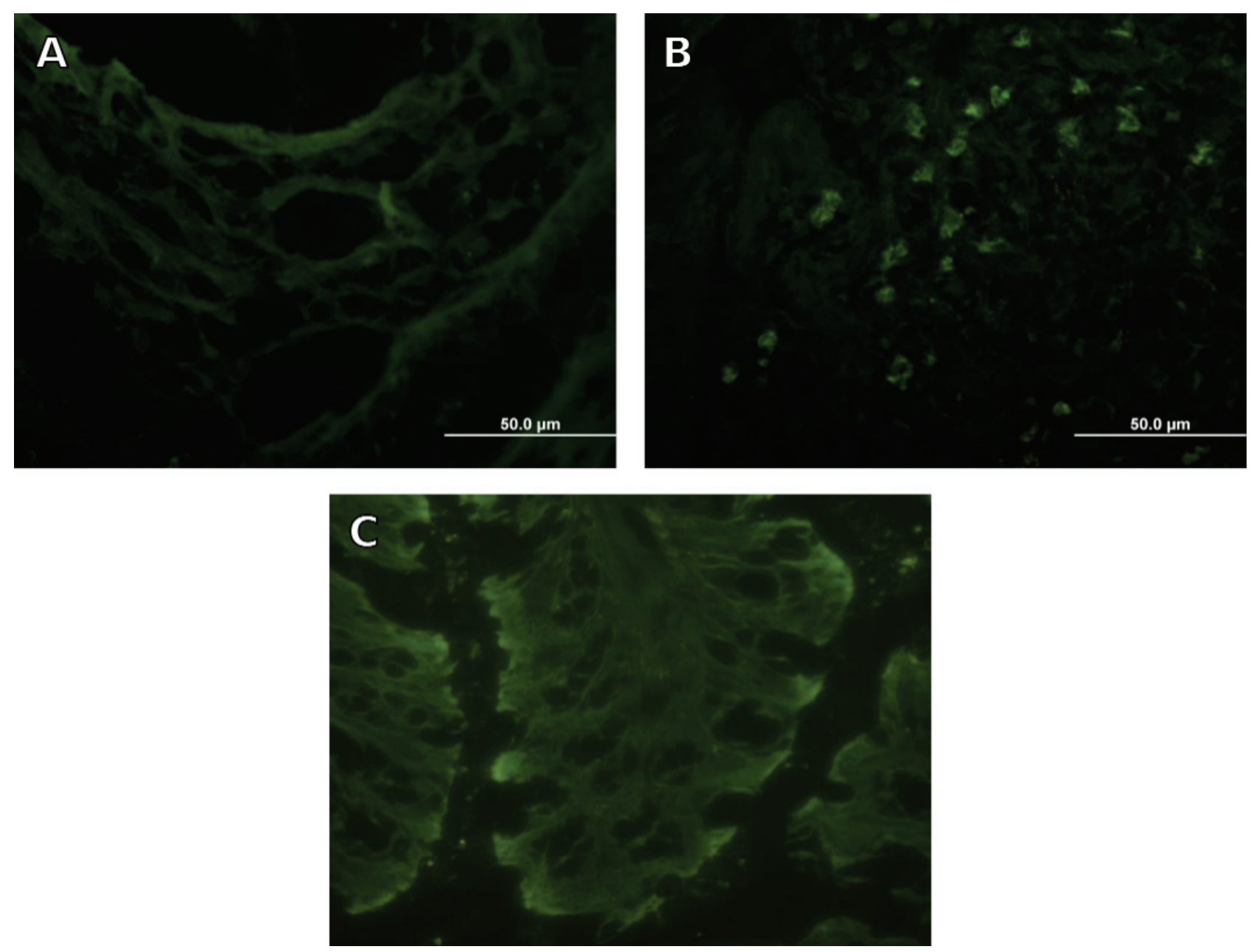

Fig. 3. Immunohistochemical detection of inflammation-induced infiltrated cells using FITC labeled anti-CD11/b in chronic DSS colitis. (A) B. ovatus-monoassociated BALB/C mice (no infiltration of inflammatory cells), (B) conventional BALB/C mice (massive infiltration of cells in lamina propria), (C) B. ovatus-monoassociated SCID mice (no infiltration of inflammatory cells).

the long-term treatment with DSS (7 days DSS, 7 days water, 7 days DSS) and therefore the values of damage score and mucin production for this group are not given in Table 2. Germ-free BALB/c mice showed mild histological changes in colon mucosa (damage score 1-2, Fig. 1A and Table 2). According to Cooper et al. (1993) degree 1 of damage stands with crypt shortening by $1 / 3$, with epithelial dilatation and thinning, with $25 \%$ damage of colon mucosa. Damage is accompanied with appearance of a hyaline layer between crypt base and muscularis mucosae indicating early colon damage, thinning of the pericryptal collagen sheath, mild increase in collagen content between crypts and mucin production in $100 \%$ colon surface. Degree 2 of damage corresponds to $26-50 \%$ damage to colon mucosa, crypt shortening by $2 / 3$ and mucin production in $75 \%$ colon surface. On the other hand, $\mathrm{CV} \mathrm{BALB} / \mathrm{c}$ mice exhibited a gross destruction of the colon mucosa, disappearance of crypts followed by infiltration of inflammatory cells, damage score 4, no mucin secretion - grade 0 (Fig. 1B and Table 2). This finding corresponds to our previous studies (Hudcovic et al. 2001). According to Cooper et al. (1993) degree 4 stands with early epithelial hyperplasia in less than $2 / 3$ of the crypts with the loss of mucin, increased mitotic activity, large inflammation in mucosa and submucosa and mucin production in $25 \%$ colon surface.

To study the influence of $B$. ovatus on the development of intestinal inflammation, GF BALB/c and SCID mice were monoassociated with $B$. ovatus and were treated in a chronic model of ulcerative colitis by two cycles with $2.5 \%$ DSS in drinking water (7 days DSS, 7 days water, 7 days DSS). We found that B. ovatus protected both BALB/c and SCID mice from bleeding and precocious death observed after long-lasting DSS treatment in their GF counterparts and from severe forms of intestinal inflammation. The values of damage score 
Table 3. Brush border enzyme activities (nkat/ $\mathrm{mg}$ protein) in mouse jejunum after monoassociation with $B$. ovatus in chronic model of ulcerative colitis in SCID mice

\begin{tabular}{lccc}
\hline Enzymes & $\begin{array}{c}\text { Untreated controls } \\
\text { GF }\end{array}$ & $\begin{array}{c}\text { B. ovatus-monoassociated, } \\
\text { controls }\end{array}$ & $\begin{array}{c}\text { B. ovatus-monoassociated, } \\
\text { DSS treated }\end{array}$ \\
\hline Lactase & $3.9 \pm 0.84$ & $5.20 \pm 0.34$ & $2.78 \pm 1.33^{*}$ \\
Sucrase & $12.42 \pm 2.82^{* *}$ & $25.49 \pm 0.69$ & $27.49 \pm 1.06$ \\
Glucoamylase & $10.33 \pm 1.54$ & $8.85 \pm 0.24$ & $8.82 \pm 0.79$ \\
DPP IV & $5.93 \pm 0.72$ & $6.38 \pm 0.12$ & $7.24 \pm 0.13$ \\
GGT & $9.10 \pm 1.46$ & $10.12 \pm 0.40$ & $6.50 \pm 0.29^{*}$ \\
Alkaline Phosphatase & $8.19 \pm 0.62$ & $7.32 \pm 0.25$ & $5.28 \pm 0.47^{*}$ \\
\hline
\end{tabular}

Values are expressed as the means \pm S.D. $* P<0.05, * * P<0.01$ significantly different from $B$. ovatus-monoassociated controls.

and mucin production were in $B$. ovatus-colonized $\mathrm{BALB} / \mathrm{c}$ mice of grade $0-1$ and in $B$. ovatus-colonized SCID mice of grade 1-2 (Fig. 2A, 2B and Table 2).

Infiltration by inflammatory cells of the intestine is a marker of the inflammatory processes. Using monoclonal antibody to CD11/b, a membrane marker of polymorphonuclear leukocytes, monocytes and natural killer cells, we found that the colon of BALB/c monocolonized with $B$. ovatus and treated with DSS did not exhibit infiltration by these cells (Fig. 3A). On the other hand, massive infiltration of pro-inflammatory cells in lamina propria occurred in conventional $\mathrm{BALB} / \mathrm{c}$ mice treated with DSS (Fig. 3B). SCID mice monocolonized with $B$. ovatus and treated with DSS did not exhibit infiltration by these cells (Fig. 3C).

The enterocyte brush-border enzymes - lactase, sucrase, glucoamylase, alkaline phosphatase, $\gamma$-glutamyltranspeptidase (GGT) and dipeptidyl peptidase IV - were determined in jejunum of GF and B. ovatusmonoassociated SCID mice. This part of the intestine has not shown histological changes in experimental colitis. Specific activities of enterocyte enzymes of $B$. ovatusmonoassociated mice treated with DSS were compared with enzyme activities detected in brush borders from B. ovatus-monoassociated DSS-untreated mice. Though we did observe only mild morphological changes in colonic mucosa (Table 2), some enterocyte brush-border enzyme activities were reduced as a consequence of DSS treatment (Table 3). In DSS-treated mice monocolonized with B. ovatus, specific activity of GGT, which is very sensitive to oxidative stress, was markedly lower compared to controls. Similarly, lactase and alkaline phosphatase activities in DSS-treated mice were significantly reduced compared with controls. Enzyme activities of untreated GF controls are given for comparison (Table 3). Lower expression of sucrase activity in untreated GF control than in B. ovatusmonoassociated control is due to delayed maturation in GF animals.

We studied also brush-border enzyme activities in chronic model of colitis under conventional conditions. However, for high mortality rate in this group of animals, we had to shorten the duration of DSS treatment to one week (acute form of colitis). In this acute colitis (B. ovatus and DSS-treated group) we obtained again a decrease of some enzyme activities compared with conventionally reared DSS-untreated mice. Activities of GGT, glucoamylase and alkaline phosphatase decreased from $5.0 \pm 0.8$ to $2.4 \pm 0.2,24.0 \pm 2.8$ to $6.7 \pm 0.3$ and $9.6 \pm 1.3$ to $5.2 \pm 0.4 \mathrm{nkat} / \mathrm{mg}$ protein, respectively.

\section{Discussion}

The composition of gut microflora plays the main role in maintaining physiological and immune homeostasis as well as in regulating host inflammatory responses. Animal models of intestinal inflammation are essentially associated with the presence of commensal intestinal microbiota. This was demonstrated by development of severe colitis in rodents raised under $\mathrm{CV}$ conditions, and by the lack of colitis in GF animals (Ehrhardt et al. 1997, Schultz et al. 2004). Our previous and present results, however, concerning chronic forms of DSS-induced inflammation in GF SCID mice contradict these studies (Hudcovic et al. 2001). When chronic DSScolitis was induced in GF SCID mice, they did not survive the long-term treatment with DSS. Similarly, in contrast to $\mathrm{BALB} / \mathrm{c}$ mice increased mortality was observed in sensitive mouse strain IQI/Jic after oral administration of $5 \%$ DSS (Kitajima et al. 2001). It was 
suggested that DSS is impairing the intestinal barrier (Okayasu et al. 1990, Kitajima et al. 2002). Direct cytotoxic effect of DSS leading to destruction of mucosal architecture, rather than infiltration by inflammatory cells could be the explanation of precocious death in susceptible mouse strains (Schultz et al. 2004).

Our main finding, i.e. that a single bacterial strain $-B$. ovatus administered intragastrically to GF $\mathrm{BALB} / \mathrm{c}$ and SCID mice prior to DSS treatment protected mice against the development of chronic colitis indicates that the intestine of GF mice can be easily colonized with $B$. ovatus and that mucosal barrier integrity was not altered. Similar results were described for colonization with B. vulgatus (Sydora et al. 2005). The mechanisms of protective activity of $B$. ovatus colonization are not fully elucidated. It can be speculated that colonization with $B$. ovatus increased the mucosal barrier integrity and thus the resistance to DSS treatment. Recently it has been hypothesized whether the inflammatory effects participate in tight junction alteration during infection. The authors suggest that only direct bacterial contact with epithelial layer significantly affects tight junction structure (Guttman et al. 2006). Protection of GF mice from DSS injury was also observed after monocolonization with probiotic E. coli Nissle 1917 but not with pathogenic E. coli O6K13 (Hudcovic et al. 2007). Protection against DSS treatment was demonstrated only in originally GF mice after monocolonization with $B$. ovatus. Intragastric administration of $B$. ovatus to conventional mice prior to and during DSS treatment led to more pronounced reduction of body weight and even to precocious death of animals with severe enterocolitis (results not shown). Interaction of component of microflora with B. ovatus is probably crucial in worsening of the experimental intestinal inflammation. In conventional environment the association of $B$. ovatus with other bacteria of higher luminal concentration may add to alterations of epithelial integrity and potentiate developing inflammation as was the case of conventionally raised SCID mice in our studies. Similarly, other bacterial strains were considered to play important role in mediating inflammation in which B. vulgatus plays a key role (Rath et al. 1999).

The effects of colonization of GF healthy animals on brush border enterocyte enzyme activities indicate the impact of microbiota on physiological digestive processes (Kozáková et al. 1998, 2001, 2006). In this study the levels of jejunal brush-border enzymes lactase, GGT and alkaline phosphatase in B. ovatus monoassociated SCID mice under the effect of DSS were significantly reduced compared to controls monoassociated with $B$. ovatus without DSS treatment. Interestingly, decreased activity of GGT in isolated brush-border membrane of jejunum was observed, even if intestinal inflammation did not develop in either B. ovatus-monocolonized GF SCID or BALB/c mice treated with DSS. Similarly, decreased mucosal activity of GGT was found not only in inflamed ileum of patients with Crohn's disease but also to a lesser extent in noninflamed ileum (Sido et al. 1998). Thus, in terms of decreased activity of GGT in our study and increased IL-18 expression (Siegmund et al. 2001, Sivakumar et al. 2002), inflammation in DSS-induced colitis mimics human Crohn's disease. The decreased activity of GGT was recently localized to lamina propria T-cells in IBD mucosa in an active state of inflammation (Reyes et al. 2005). Our observation localizes for the first time the impaired GGT to jejunal brush-border membrane of SCID mice lacking T-cells, and supports the notion that the treatment with DSS led to structural changes in small intestinal mucosa where no direct inflammation was produced. In patients with IBD infiltrating macrophages and neutrophils are abundantly present in inflamed gut and participate in substantial oxidative stress by producing reactive oxygen radicals that lead to oxidative damage to colon protein and impaired glutathione synthesis (Sido et al. 1998). Among other enzymes, GGT is involved in the synthesis and homeostasis of glutathione, an antioxidant defense system, effective in reducing reactive oxygen species (ROS). In experimental ulcerative colitis the antioxidant defense system is impaired (Nieto et al. 2000). An imbalance between prooxidant and anti-oxidant mechanisms increases the susceptibility to oxidative tissue injury.

Similarly alkaline phosphatase, a dephosphorylating enzyme may play an important role in host defense system against pathological stress such as inflammation and infection (Harada et al. 2003). Reduced jejunal lactase and alkaline phosphatase in patients with ulcerative colitis was described by Arvanitakis (1979). Reduced glucoamylase in acute experimental colitis, which in healthy animals is most abundant on the tips of villi as seen from villus-crypt gradient (Kolínská et al. 1990), might be associated with some injury in the small intestine just on the villi tips. Interestingly, the villus-crypt gradient of sucrase showed a broad maximum activity down to the middle of the villus and thus no decrease in sucrase activity was noticed in experimental colitis. 
In summary, these observations provide data on the protective property of B. ovatus to prevent death as a consequence of long-term DSS treatment in GF SCID and $\mathrm{BALB} / \mathrm{c}$ mice. Though DSS-treated B. ovatusmonocolonized SCID mice showed minor morphological changes in the colon, DSS treatment caused a decrease in three activities of the small intestinal brush-border enzymes (GGT, alkaline phosphatase, lactase) as compared to DSS-untreated GF or B. ovatusmonoasssociated mice. Especially the localization of altered GGT activity to enterocyte brush-border membrane represents a new finding. Until now lamina propria $\mathrm{T}$ cells have been considered as the main locus of GGT changes in an active state of inflammation.

\section{Conflict of Interest}

There is no conflict of interest.

\section{Acknowledgements}

We thank Mrs. I. Grimová, A. Smolová and B. Ságnerová for excellent technical assistance. This manuscript was supported by grants 303/04/0849, 303/08/0367, $303 / 05 / 2249$ and 303/06/0974 of Czech Science Foundation, grants 2B06053 and 2B06155 of the Ministry of Education, Youth and Sports, grant S500200572 of Grant Agency of the Academy of Sciences and by Institutional Research Concepts No. AV0Z50200510 and AV0Z50110509.

\section{References}

ARVANITAKIS C: Abnormalities of jejunal enzymes in ulcerative colitis and Crohn's disease. Digestion 19: 259-266, 1979.

AXELSSON LG, LANDSTRÖM E, GOLDSCHMIDT TJ, GRONBERG A, BYLUND-FELLENIUS AC: Dextran sulfate sodium (DSS) induced experimental colitis in immunodeficient mice: effects in CD4 ${ }^{+}$-cell depleted, athymic and NK-cell depleted SCID mice. Inflam Res 45: 181-191, 1996.

COOPER HS, MURTHY SN, SHAH RS, SEDERGRAN DJ: Clinopathologic study of dextrane sulfate sodium experimental murine colitis. Lab Invest 69: 238-249, 1993.

DAHLQVIST A: Method for assay of intestinal disaccharidases. Anal Biochem 7: 18-25, 1964.

DIELEMAN LA, RIDWAN BU, TENNYSON GS, BEAGLEY KW, BUCY RP, ELSON CO: Dextran sulfate sodiuminduced colitis occurs in severe combined immunodeficient mice. Gastroenterology 107: 1643-1652, 1994.

EHRHART RO, LÚDVÍKSSON BR, GRAY B, NEURATH M, STROBER W: Induction and prevention of colonic inflammation in IL-2-deficient mice. J Immunol 158: 566-573, 1997.

FARKAS S, HERFARTH H, RÖSSLE M, SCHROEDER J, STEINBAUER M, GUBA M, BEHAM A, SCHÖLMERICH J, JAUCH KW, ANTHUBER M: Quantification of mucosal leukocyte endothelial cell interaction by in vivo fluorescence microscopy in experimental colitis in mice. Clin Exp Immunol 126: 250$258,2001$.

GUTTMAN JA, SAMJI FN, LI Y, VOGL AW, FINLAY BB: Evidence that tight junctions are disrupted due to intimate bacterial contact and not inflammation during attaching and effacing pathogen infection in vivo. Infect Immun 74: 6075-6084, 2006.

HARADA T, KOYAMA I, KASAHARA T, ALPERS DH, KOMODA T: Heat shock induces intestinal-type alkaline phosphatase in rat IEC-18 cells. Am J Physiol 284: G255-G262, 2003.

HOOPER LV, GORDON JI: Commensal host-bacterial relationships in the gut. Science 292: 1115-1118, 2001.

HOOPER LV: Bacterial contribution to mammalian gut development. Trends Microbiol 12: 129-134, 2004.

HUDCOVIC T, ŠTĚPÁNKOVÁ R, CEBRA J, TLASKALOVÁ-HOGENOVÁ H: The role of microflora in the development of intestinal inflammation: acute and chronic colitis induced by dextran sulfate in germ-free and conventionally reared immunocompetent and immunodeficient mice. Folia Microbiol 46: 565-572, 2001.

HUDCOVIC T, ŠTĚPÁNKOVÁ R, KOZÁKOVÁ H, HRNČíř T, TLASKALOVÁ-HOGENOVÁ H.: Effects of monocolonization with Escherichia coli strains O6K13 and Nissle 1917 on the development of experimentally induced acute and chronic intestinal inflammation in germ-free immunocompetent and immunodeficient mice. Folia Microbiol 52: 618-626, 2007. 
KESSLER M, ACUTO O, STORELLI C, MURER H, MÜLLER M, SEMENZA G: A modified procedure for the rapid preparation of efficiently transporting vesicles from small intestinal brush border membranes. Their use in investigating some properties of D-glucose and choline transport systems. Biochim Biophys Acta 506: 136-154, 1978.

KITAJIMA S, MORIMOTO M, SAGARA E, SHIMIZU C, IKEDA Y: Dextran sulfate sodium-induced colitis in germfree IQI/Jic mice. Exp Anim 50: 387-395, 2001.

KITAJIMA S, MORIMOTO M, SAGARA E, SHIMIZU C, IKEDA Y: A model for dextran sulfate sodium (DSS)induced colitis: bacterial degradation of DSS does not occur after incubation with mouse cecal contents. Exp Anim 51: 2003-206, 2002.

KOLÍNSKÁ J, KRAML J: Separation of sucrase-isomaltase and of glucoamylase of rat intestine. Biochim Biophys Acta 28: 235-247, 1972.

KOLÍNSKÁ J, KRAML J, ZÁKOSTELECKÁ M, KADLECOVÁ L: Actinomycin D suppresses hydrocortisoneinduced changes in distribution and sialylation of brush-border enzymes in jejunal villi and crypts. Biochem Int 21: 581-591, 1990.

KOZÁKOVÁ H, ŠTĚPÁNKOVÁ R, ŘEHÁKOVÁ Z, KOLÍNSKÁ J: Differences in enterocyte brush border enzyme activities in ageing rats reared in germ-free and conventional conditions. Physiol Res 47: 253-258, 1998.

KOZÁKOVÁ H, ŘEHÁKOVÁ Z, KOLÍNSKÁ J: Bifidobacterium bifidum monoassociation of gnotobiotic mice: effect on enterocyte brush-border enzymes. Folia Microbiol 46: 573-576, 2001.

KOZÁKOVÁ H, KOLÍNSKÁ J, LOJDA Z, ŘEHÁKOVÁ Z, ŠINKORA J, ZÁKOSTELECKÁ M, ŠPLÍCHAL I, TLASKALOVÁ-HOGENOVÁ H: Effect of bacterial monoassociation on brush-border enzyme activities in ex-germ-free piglets: comparison of commensal and pathogenic Escherichia coli strains. Microbes Infect 8: 2629-2639, 2006.

KRAML J, KOLÍNSKÁ J, ELLEDEROVÁ D, HIRŠOVÁ D: B-glucosidase (phlorizin hydrolase) activity of the lactase fraction isolated from the small intestinal mucosa of infant rats, and the relationship between $\beta$ glucosidases and $\beta$-galactosidases. Biochim Biophys Acta 258: 520-530, 1972.

LOWRY OH, ROSENBROUGH WJ, FARR F, RANDALL RJ: Protein measurement with Folin phenol reagent. $J$ Biol Chem 193: 265-275, 1951.

LUCKE K, MIEHLKE S, JACOBS E, SCHUPPLER M: Prevalence of Bacteroides and Prevotella spp. in ulcerative colitis. J Med Microbiol 55: 617-624, 2006.

NAGATSU T, HINO M, FUYAMAHA H, HAYAKAWA T, SAKAKIBARA S, NAKAGAWA Y, TAKEMOTO T: New chromogenic substrates for X-prolyl dipeptidylaminopeptidase. Anal Biochem 74: 466-476, 1976.

NIETO N, TORRES MI, FERNANDEZ MI, GIRON MD, RIOS A, SUAREZ MD, GIL A: Experimental ulcerative colitis impairs antioxidant defense system in rat intestine. Dig Dis Sci 45: 1820-1827, 2000.

OKAYASU I, HATAKEYAMA S, YAMADA M, OHKUSA T, INAGI Y, NAKYA R: A novel method in the induction of reliable experimental acute and chronic ulcerative colitis in mice. Gastroenterology 98: 694-702, 1990.

POXTON IR, BROWN R, SAWYERR A, FERGUSON A: Mucosa-associated bacterial flora of the human colon. J Med Microbiol 46: 85-91, 1997.

RATH HC, WILSON KH, SARTOR RB: Differential induction of colitis and gastritis in HLA-B27 transgenic rats selectively colonized with Bacteriodes vulgatus or Escherichia coli. Infect Immun 67: 2969-2974, 1999.

REYES BM, DANASE S, SANS M, FIOCCHI C, LEVINE AD: Redox equilibrium in mucosal T cells tunes the intestinal TCR signaling threshold. J Immunol 175: 2158-2166, 2005.

SAITOH S, NODA S, AIBA Z, TAKAGI A, SAKAMOTO M, BENNO Z, KOGA Z: Bacteroides ovatus as the predominant commensal intestinal microbe causing a systemic antibody response in inflammatory bowel disease. Clin Diagn Lab Immunol 9: 54-59, 2002.

SCHULTZ M, STRAUCH UG, LINDE HJ, WATZL S, OBERMEIER F, GOTTL C, DUNGER N, GRUNWALD N, SCHOLMERICH J, RATH HC: Preventive effects of Escherichia coli strain Nissle 1917 on acute and chronic intestinal inflammation in two different murine models of colitis. Clin Diagn Lab Immunol 11: 372-378, 2004.

SIDO B, HACK V, HOCHLEHNERT, LIPPS H, HERFARTH C, DRÖGE W: Impairment of intestinal glutathione synthesis in patients with inflammatory bowel disease. Gut 42: 485-492, 1998. 
SIEGMUND B, FANTUZZI G, RIEDER F, GAMBONI-ROBERTSON F, LEHR HS, HARTMANN G, DINARELLO CA, ENDRES S, EIGLER A: Neutralization of Interleukin-18 reduces severity in murine colitis and intestinal IFN- $\gamma$ and TNF- $\alpha$ production. Am J Physiol 281: R1264-R1273, 2001.

SIVAKUMAR PV, WESTRICH GM, KANALY S, GARKA K, BORN TL, DERRY JMJ, VINEY JL: Interleukin 18 is a primary mediator of inflammation associated with dextran sulphate sodium induced colitis: blocking interleukin 18 attenuates intestinal damage. Gut 50: 812-820, 2002.

SOKOL H, SEKSIK P, RIGOTTIER-GOIS L, LAY C, LEPAGE P, PODGLAJEN I, MARTEAU P, DORE J: Specificities of the fecal microbiota in inflammatory bowel disease. Inflam Bowel Dis 12: 106-111, 2006.

SYDORA BC, TAVERNINI MM, DOYLE JG, FEDORAK RN: Association with selected bacteria does not cause enterocolitis in IL-10 gene-deficient mice despite a systemic immune response. Dig Dis Sci 50: 905-913, 2005.

ŠTĚPÁNKOVÁ R: Rearing of germ-free rats, mice, and rabbits. In: Immunology Methods Manual LEFKOVITS I (ed), Gnotobiological Models TLASKALOVÁ H, ŠTERZL J (eds), Academic Press, New York, 1997, pp 15371542.

THOMPSON GA, MEISTER A: Hydrolysis and transfer reactions catalyzed by gamma-glutamyl transpeptidase; evidence for separate substrate sites and for high affinity of L-cystine. Biochem Biophys Res Commun 71: 32$36,1976$.

TLASKALOVÁ-HOGENOVÁ H, TUČKOVÁ L, ŠTĚPÁNKOVÁ R, HUDCOVIC T, PALOVÁ-JELÍNKOVÁ L, KOZÁKOVÁ H, ROSSMANN P, SANCHÉZ D, CINOVÁ J, HRNČÍǏ T, KVERKA M, FROLOVÁ L, UHLIG H, POWRIE F, BLAND P: Involvement of innate immunity in the development of inflammatory and autoimmune diseases. Ann N Y Acad Sci 1051: 787-798, 2005. 